Artikel Penelitian

\title{
Studi Karakteristik dan Uji Aktivitas Antioksidan dari Tepung Buah Okra (Abelmoschus esculentus)
}

\section{Study of Okra Fruit Powder (Abelmoschus Esculentus) Characteristics and Test of Antioxidant Activities}

Ahdiyatul Fauza1, Kis Djamiatun², Ahmad Ni'matullah Al-Baarri3*

${ }^{1}$ Magister IImu Gizi, Fakultas Kedokteran, Universitas Diponegoro, Semarang

2Fakultas Kedokteran, Universitas Diponegoro, Semarang

${ }^{3}$ Program Studi Teknologi Pangan, Fakultas Peternakan dan Pertanian, Universitas Diponegoro, Semarang

*Korespondensi dengan penulis (albari@live.undip.ac.id)

Artikel ini dikirim pada tanggal 06 Maret 2019 dan dinyatakan diterima tanggal 26 Oktober 2019. Artikel ini juga dipublikasi secara online melalui https://ejournal2.undip.ac.id/index.php/jatp. Hak cipta dilindungi undang-undang. Dilarang diperbanyak untuk tujuan komersial.

Diproduksi oleh Indonesian Food Technologists ${ }^{\circledR}(2019$

\begin{abstract}
Abstrak
Penelitian ini bertujuan untuk mengetahui aktivitas antioksidan saat sebelum dan setelah pengeringan buah Okra. Analisis fisik meliputi analisis warna dan PSD (Particle Size Distribution). Analisis kimia meliputi uji pH, conductivity dan TDS (Total Disolve Solid). Uji aktivitas antioksidan dilakukan dengan metode DPPH. Analisis data warna menggunakan uji korelasi. Data PSD, uji pH, konduktivitas, TDS, dan aktivitas antioksidan disajikan secara deskriptif. Hasil penelitian menunjukkan bahwa pengeringan buah Okra menjadi tepung Okra, tidak merusak aktivitas antioksidan. Proses pengeringan tepung Okra meningkatkan derajat kecerahan Okra dengan hasil uji statistik nilai $L^{*}<0,0001$ dan $a^{*} 0,0002(p<0,05)$. Distribusi ukuran partikel tepung Okra lebih kecil sehingga mudah larut dalam air. Buah Okra memiliki pH yang lebih asam yang mengakibatkan konduktivitasnya menjadi lebih tinggi sehingga padatan yang terlarut (kation, anion, mineral) juga semakin tinggi. Kesimpulannya, aktivitas antioksidan tepung buah Okra dapat diidentifikasi baik sebelum maupun setelah pengeringan dan proses pengeringan dapat berhasil memelihara aktivitas antioksidannya.
\end{abstract}

Kata kunci : Okra, aktivitas antioksidan, pengeringan, oven, uji karakteristik

\begin{abstract}
This study aims to determine the physical, chemical, and antioxidant activities before and after drying the Okra fruit. Color analysis and PSD (Particle Size Distribution) were measured for physical analysis. pH test, conductivity, and TDS (Total Disolve Solid) was also measured as chemical analysis. Antioxidant activity was tested using DPPH. Color data was analyzed using correlation test. PSD data, $\mathrm{pH}$ test, conductivity, TDS, and antioxidant activity were presented descriptively. The results showed that drying Okra fruit to produce Okra flour did not damage antioxidant activity. The drying process of Okra flour brightening the color of the Okra fruit and in accordance with the statistical test that was resulted value of $L^{*}<0.0001$ and $a^{*} 0,0002(p<0.05)$. The particle size distribution of Okra flour was categorized as small. A much more acidic $\mathrm{pH}$ and higher in conductivity were found in the fresh Okra. As conclusion, antioxidant activity of Okra flour could be determined and the drying may be applied since able to maintain antioxidant activity in Okra flour.
\end{abstract}

Keywords : Okra, antioxidant activity, drying, oven, characteristic analysis

\section{Pendahuluan}

Buah Okra (Abelmoschus esculentus) termasuk famili Malvaceae, yaitu tanaman asli Afrika dan India dan telah menjadi bagian dari diet di berbagai belahan dunia (EI SN, 2004). Studi fitokimia menunjukkan bahwa polisakarida, polifenol, flavonoid, tanin, sterol dan triterpen adalah komponen utama $A$. esculentus dengan berbagai aktivitas biologis terutama pada kulit dan biji Okra (Sheu et al., 2012; Arapitsas, 2008). Studi menunjukkan bahwa buah Okra kaya komponen bioaktif, seperti flavonoid, terutama kuersetin dan pitosterol (Sa'eed et al., 2016). Okra segar memiliki flavonoid yakni kuersetin dalam jumlah 60-75\% (Zhu et al., 2000; Roy et al., 2014). Buah Okra memiliki fenol dan flavonoid yang memiliki efek antioksidan dan efek anti diabetik

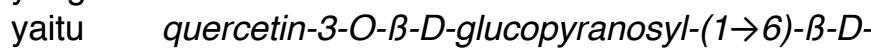
glucopyranoside dan quercetin-3-O-B-D-4"-O-methyl- $\beta$ $D$-glucopyranoside (Zhang, 2014). Kuersetin yang merupakan komponen bioaktif berperan sebagai antioksidan sehingga dapat mencegah dan melindungi dari stres oksidatif (Coskun et al., 2005), dan menurunkan tekanan darah (Edwards et al., 2018). Kondisi stres oksidatif yang disebabkan peningkatan kadar glukosa dalam darah dapat menyebabkan penyakit diabetes melitus, yang apabila tidak diobati dapat berujung pada komplikasi (Giacco and Brownlee, 2014). Okra seperti kebanyakan sayur lainnya, mengandung antioksidan yang berperan dalam menangkal radikal bebas, serta mengatasi kelelahan (fatigue). Hal ini disebabkan stres oksidatif juga berperan dalam menyebabkan kelelahan (Filler et al., 2014; Lin et al., 2014). Hasil penelitian lain menyebutkan bahwa tepung Okra memiliki potensi sebagai antidiabetes dan antihiperlipidemia pada hewan coba tikus (Sabitha et al., 2012; Fan et al., 2014). Serat makanan dan polifenol yang berlimpah ditemukan di buah Okra, dapat 
berkontribusi terhadap efek hipoglikemik dan hipolipidemik (Arapitsas, 2008).

Proses pengeringan dapat meningkatkan konsentrasi komponen bioaktif seperti karotenoid (Juin et al., 2012; Pellegrini et al., 2009; Bernhardt and Schlich, 2006) dan kuersetin (Lombard et al., 2005). Selain itu, proses pengeringan juga meningkatkan aktivitas antioksidan (Turkmen et al., 2005), meningkatkan bioaksesibilitas komponen bioaktif (Pellegrini et al., 2009), kapasitas antioksidan total (Miglio et al., 2008) dan total fenol (Chumyam et al., 2013). Buah Okra lebih kaya akan nutrisi dalam bentuk kering (Adelakun et al., 2009). Oleh sebab itu perlu dilakukan penelitian untuk melihat karakteristik Okra dan aktivitas antioksidan setelah dikeringkan menjadi tepung. Penelitian ini bertujuan untuk mengetahui karakteristik fisik, kimia, dan aktivitas antioksidan saat sebelum dan setelah pengeringan buah Okra. Pengeringan pada suatu bahan makanan sangat penting karena dapat memperpanjang umur simpan. Pengeringan dapat berlangsung dengan baik, jika pemanasan terjadi pada setiap tempat dari bahan tersebut, dan uap air yang diambil berasal dari semua permukaan bahan tersebut.

Penelitian mengenai pengolahan Okra sudah pernah dilakukan, dengan perlakuan berupa perendaman, blansir, malting dan pemanggangan biji Okra terhadap kandungan mineral dan sifat fungsionalnya (Adelakun et al., 2009), sedangkan penelitian Okra dalam tekstur tepung masih jarang dilakukan. Okra dalam tekstur tepung memiliki daya simpan yang lama, nilai ekonomis yang tinggi, kandungan zat gizi dan senyawa bioaktif yang lebih banyak.

\section{Materi dan Metode \\ Materi}

Okra yang digunakan dalam penelitian ini bisa didapatkan di pasar tradisional Semarang, persiapan pembuatan tepung Okra dan pemeriksaan aktivitas antioksidan tepung Okra dilakukan di Laboratorium Terpadu Universitas Diponegoro. Semua alat dan bahan yang digunakan selama penelitian diperoleh dari Laboratorium Terpadu Universitas Diponegoro. Peralatan yang digunakan selama penelitian antara lain timbangan analitik, $\mathrm{pH}$ meter, digital color meter software (Macintosh, US), studio mini $30 \times 20 \times 40 \mathrm{~cm}$ dengan jumlah pencahayaan 50 lumen, cabinet dryer (Getra, Taiwan), shieving (Retsch, Jerman) dan spektrofotometer UV-1280 (Shimadzu, Japan).

\section{Metode}

Penelitian berlangsung selama bulan September hingga Oktober 2018. Pengeringan buah Okra menggunakan cabinet dryer dengan suhu $40^{\circ} \mathrm{C}$ selama 11 jam.

\section{Proses Pembuatan Tepung Okra}

Buah Okra dicuci bersihkan dengan air dan dibuang tangkainya, dipotong-potong kemudian di blender untuk menghaluskan. Pengeringan menggunakan cabinet dryer dengan suhu $40^{\circ} \mathrm{C}$ selama 11 jam. Setelah kering dihaluskan dengan blender agak menjadi bubuk kemudian diayak menggunakan ayakan 60 mesh.

\section{Karakteristik Fisik Warna}

Analisa warna dilakukan dengan menggunakan alat Digital Color Meter dengan bantuan software dari Apple Macintosh. Pengukuran dilakukan dengan meletakkan sampel di dalam wadah sampel ke dalam mini studio dengan lampu led dengan kekuatan 50 lumen. Selanjutnya dilakukan pengukuran nilai $L^{*}, a^{*}$, dan nilai $b^{*}$ terhadap sampel dengan menggunakan kamera iSight (Apple, US). Model warna terdiri dari tiga komponen $L^{*}$ (lightness) yang dimulai dari nilai 0 (hitam) sampai 100 (putih) dan komponen $a^{*}$ mewakili tingkat warna merah-hijau dengan level +60 adalah merah dan -60 adalah hijau, serta komponen $b^{*}$ mewakili biru sampai kuning, yang merupakan dua komponen kromatik dengan kisaran nilai -120 (biru) sampai +120 (kuning) (Mendoza et al,. 2007).

\section{Pengukuran PSD (Particle Size Distribution)}

Distribusi ukuran partikel tepung tepung Okra diukur dengan menggunakan ayakan bertingkat dengan ukuran 60 mesh, 120 mesh, dan 230 mesh, yang disusun berturut-turut dari atas ke bawah. Tepung dimasukkan melalui ayakan di bagian paling atas yang berukuran paling besar, kemudian pengayak digetarkan selama 5 menit hingga tepung turun ke bagian dasar. Jumlah tepung yang tertinggal pada masing-masing ayakan ditimbang dan dihitung persentasenya (Imanningsih, 2012).

\section{Perhitungan Kadar Air}

Kadar air tepung merupakan salah satu parameter yang sangat berpengaruh terhadap umur simpan tepung. Kadar air suatu produk sangat penting dikendalikan karena dapat menentukan daya tahan atau keawetan produk yang bersangkutan pada waktu penyimpanan. Tinggi atau rendahnya kadar air tepung dipengaruhi oleh proses pengeringan. Semakin tinggi kadar air bahan pangan, maka semakin cepat rusaknya, baik akibat adanya aktivitas biologis internal maupun masuknya mikroba perusak. Mikroorganisme membutuhkan air untuk pertumbuhan dan perkembangbiakannya. Jika kadar air pangan dikurangi, pertumbuhan mikroorganisme akan diperlambat (Pangesti et al,. 2014). Kadar air dihitung dengan menimbang berat Okra pada tiap jam pengeringan hingga berat konstan.

\section{Uji pH, Konduktivitas dan TDS (Total Dissolve Solid)}

Uji pH dilakukan dengan menggunakan $\mathrm{pH}$ meter pada tepung Okra yang sudah dilarutkan dengan aquades dengan perbandingan 1:1. Perhitungan $\mathrm{pH}$ pada Okra segar juga digunakan aquades sebagia pelarut. Uji pH dilakukan pengulangan sebanyak 2 kali. Uji konduktivitas dilakukan dengan menggunakan conductivity meter dengan cara yang sama dengan 
pengukuran $\mathrm{pH}$. Uji TDS dilakukan dengan menggunakan TDS meter dan dilakukan dengan mekanisme pengukuran yang sama dengan cara pengukuran $\mathrm{pH}$.

\section{Uji Aktivitas Antioksidan}

Analisis aktivitas antioksidan dengan metode DPPH adalah mengacu pada metode (Suica-Bunghez et al., 2016). Persiapan larutan DPPH dilakukan dengan menggunakan methanol $(0,02 \mathrm{mg} \mathrm{DPPH} / \mathrm{ml} \mathrm{MeOH})$ dengan warna violet. Sebanyak 0,045 g sampel tepung Okra dicampur dengan $1 \mathrm{ml}$ larutan DPPH yang kemudian diinkubasi di tempat gelap selama 1 jam. Setelah itu, campuran tersebut dibaca absorbansinya pada $\lambda=517 \mathrm{~nm}$ dengan spektrofotometer. Kontrol dibuat dari $0,5 \mathrm{ml} \mathrm{MeOH}$ dengan $1 \mathrm{ml}$ larutan DPPH. Aktivitas antioksidan (AA\%) dihitung dengan formula absorbansi control dikurangi absorbansi sampel lalu dibagi dengan absorbansi kontrol yang kemudian dikali 100 .

\section{Analisis Statistik}

Data warna yang diperoleh dianalisis menggunakan uji correlation dengan GraphPad Prism. Hasil analisis dikatakan signifikan jika nilai $p<0,05$. Pengolahan data warna dianalisis menggunakan program statistik komputer.

\section{Hasil dan Pembahasan}

Karakteristik Fisik Warna

Berdasarkan Figur 1, nilai $L^{*}$ cenderung meningkat tajam $(p<0,05)$ dari jam 0 sampai jam ke-11 yang menandakan bahwa kecerahan Okra meningkat seiring dengan lama pengeringan. Nilai $a^{*}$ cenderung rendah (dibawah nol) baik pada awal pemanasan maupun setelah pemanasan 11 jam yang menandakan bahwa warna yang terbentuk adalah cenderung mempunyai warna hijau dan tampak warna hijau menjadi signifikan berkurang $(p<0,05)$ seriring dengan lamanya pemanasan. Nilai $b^{*}$ pada awal pemanasan tampak mempunyai nilai +29 yang berarti cenderung berwarna kuning yang kemudian meningkat warna kuningnya dengan nilai +47 sampai dengan jam pemanasan ke-8, namun setelah itu, tampak adanya penurunan menjadi bernilai +27 . Perubahan yang terjadi pada nilai $b^{*}$ ini, secara statistik menunjukkan tidak adanya perbedaan yang signifikan $(p>0,05)$.

Terdapat perbedaan yang signifikan pada nilai $L^{*}$ yang menandakan Okra setelah menjadi tepung, warna menjadi yang jauh lebih cerah yang sejalan dengan penelitian yang dihasilkan oleh peneliti lain (Dadali et al, 2017). Nilai $L^{*}$ yang semakin cerah ini linear penelitian hasil yang didapat dari nilai $\mathrm{a}^{*}$ yang keduanya menunjukkan adanya peningkatan yang sigifikan, yang menandakan bahwa Okra setelah menjadi tepung dapat berwarna lebih cerah dan kehilangan warna hijau. Nilai $a^{*}$ ini yang diduga dipengaruhi kandungan karotenoid likopen, yang berarti bahwa selama proses pengeringan, karatenoid likopen mungkin berkurang jumlahnya, sedangkan nilai $b^{*}$ diduga menunjukkan kadar $\beta$-karoten yang mempunyai warna oranye (Sacks and Francis,
2001), sehingga oleh karena tidak mengalami perubahan yang signifikan selama proses pengeringan maka kemungkinan proses pengeringan tidak menyebabkan dampak yang nyata pada kadar $\beta$ karoten. Kalaupun terjadi penurunan nilai $b^{*}$ mungkin disebabkan dekomposisi klorofil, karotenoid atau adanya proses pencoklatan non-enzimatik (Dadali et al, 2017).

\section{Analisis Particle Size Distribution}

Berdasarkan Figur 2, dapat disimpulkan bahwa proporsi terbesar partikel tepung Okra adalah berdiameter $125 \mu \mathrm{m}$ dengan distribusi partikel sebesar 47,696 persen dan hanya sedikit yang memiliki diameter partikel $<125 \mu \mathrm{m}$, yaitu 3,404 persen. Ukuran partikel memegang peran penting dalam menentukan kualitas tepung karena dapat secara langsung berhubungan dengan penyerapan air pada tepung. Makin besar ukuran partikel, maka luas permukaannya semakin kecil, sehingga air memerlukan waktu yang lebih lama untuk diabsorpsi ke dalam partikel tepung dan kemungkinan dapat membentuk partikel yang kompak yang mengakibatkan proses kelarutan partikel tersebut makin berkurang (Al-Baarri et al., 2019). Sebaliknya, ukuran partikel lebih kecil dapat meningkatkan laju hidrasi tepung (Alpizar-Reyes et al., 2017). Tepung Okra tidak memiliki ukuran partikel yang lebih besar dari $250 \mu \mathrm{m}$ yang artinya dapat secara mekanis terpecah menjadi partikel yang lembut. Besarnya jumlah partikel yang pada ukuran $125 \mu \mathrm{m}$ dapat juga dikarenakan partikel tersebut saling menempel dan tidak dapat lepas dari saringan, Distribusi ukuran partikel diukur untuk memastikan kualitas konstan tepung, flowability, kepadatan, kompresibilitas yang artinya bahwa semakin tinggi partikel halus (yang $<250 \mu \mathrm{m}$ ) maka semakin banyak yang dapat terabsorpsi. Berdasarkan penelitian ini didapatkan data bahwa ukuran partikel yang lebih kecil $<250 \mu \mathrm{m}$ adalah berkisar 7)\% sehingga dapat diasumsikan bahwa tepung Okra dapat terabsorbsi dengan baik (Carpin et al., 2017).

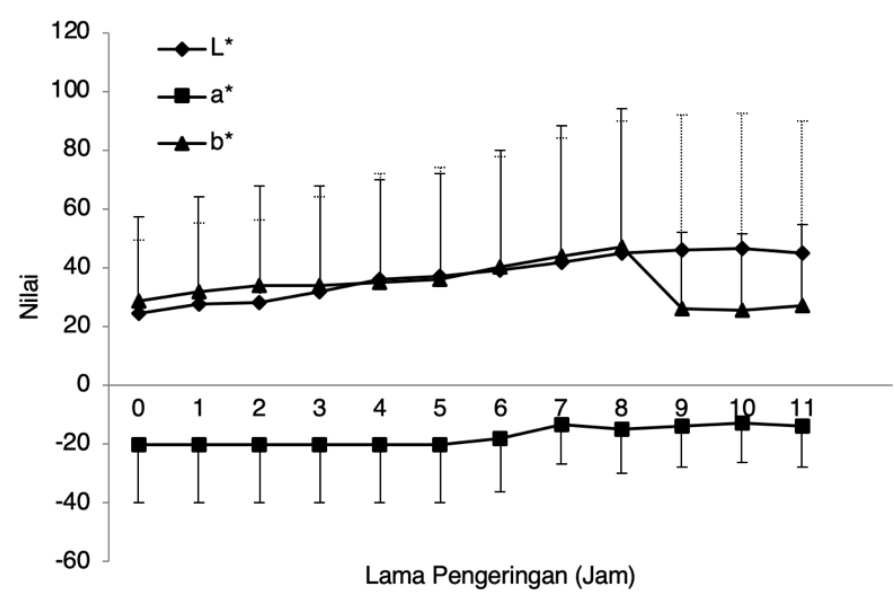

Figur 1. Grafik nilai $L^{*}, a^{*}, b^{\star}$ pada biji Okra selama proses pengeringan selama 11 jam pada suhu $40^{\circ} \mathrm{C}$ 


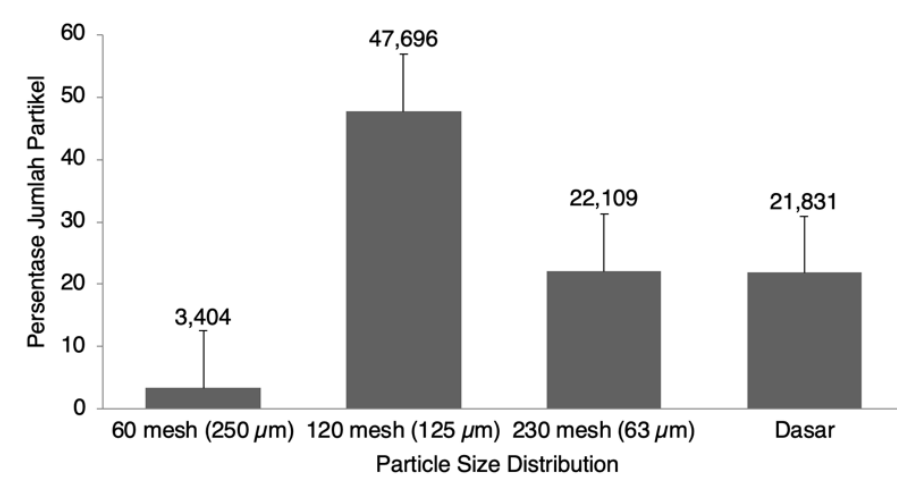

Figur 2. Persentase distribusi ukuran partikel tepung Okra yang telah dikeringkan selama 11 jam

\section{Analisis Kadar Air}

Kadar air buah Okra yaitu $89,7 \%$, sedangkan tepung Okra memiliki kadar air 8,37\% (Tabel 2). Kadar air ini sangat menentukan umur simpan karena berkaitan dengan Aw (Activity of water), dengan semakin tingginya kadar air maka semakin besar kemungkinan untuk terkontaminasi oleh bakteri. Hasil penelitian ini nampaknya dalam rentang hasil penelitian lainnya bahwa kadar air Okra berkisar antara 89,647 hingga 90,581\% (Adelakun et al., 2009). Kadar air tepung Okra dinilai hampir tidak jauh beda dengan hasil penelitian lain yang berkisar antara 8,51 hingga 9,36\% (Ubwa et al., 2014). Tidak berbeda jauhnya hasil ini dapat terjadi karena perlakuan suhu yang relatif tidak jauh berbeda. Kadar air sangat berpengaruh terhadap mutu bahan pangan, hal ini merupakan salah satu sebab mengapa di dalam pengolahan pangan air tersebut sering dikeluarkan atau dikurangi dengan cara penguapan atau pengentalan dan pengeringan yang bertujuan untuk memperlama kadaluarsa dan mengurangi besar serta berat bahan pangan (Krokida et al., 2003).

Nilai pH, Konduktivitas, dan TDS

Berdasarkan Tabel 2 dapat disimpulkan bahwa nilai $\mathrm{pH}$ dari buah Okra lebih rendah daripada tepung Okra. Jika suatu produk pangan semakin asam atau rendah maka dapat berdampak pada nilai konduktivitas yang tinggi sebagaimana tingginya nilai konduktivitas pada buah Okra. Nilai konduktivitas menunjukkan tingkat kemampuan suatu bahan untuk menghantarkan listik. Hal tersebut menunjukkan bahwa semakin asam suatu cairan sifat kelistrikannya dapat semakin baik. Konduktivitas yang tinggi dapat diartikan bahwa padatan yang terlarut (kation, anion, mineral) adalah termasuk dalam kategori tinggi. Hal ini sesuai dengan hasil uji dalam penelitian ini yaitu nilai konduktivitas dan nilai TDS pada tepung Okra adalah lebih tinggi dibandingkan dengan buah Okra.

Tabel 1. Uji korelasi nilai $L^{*}, a^{*}, b^{*}$ dengan menggunakan Graphpad prism

\begin{tabular}{|c|c|c|c|}
\hline Analisis & $L^{*}$ & $a^{*}$ & $b^{*}$ \\
\hline $\mathrm{R}$ & 0,97 & 0,87 & $-0,030$ \\
\hline $\mathrm{p}$ & $<0,0001$ & 0,0002 & 0,9266 \\
\hline SD & $0,89 \pm 0,99$ & $0,60 \pm 0,96$ & $-0,59 \pm 0,55$ \\
\hline
\end{tabular}

Tabel 2. Hasil uji karakteristik fisik, kimia dan aktivitas antioksidan buah Okra dan tepung Okra setelah pengeringan 11 jam

\begin{tabular}{lcc}
\hline Variabel & Buah Okra & Tepung Okra \\
\hline Kadar air & $89,7 \%$ & $8,37 \%$ \\
pH & 4,60 & 6,35 \\
TDS & $996 \mu \mathrm{S} / \mathrm{cm}$ & $207 \mu \mathrm{S} / \mathrm{cm}$ \\
Konduktivitas & $656 \mathrm{ppm}$ & $137 \mathrm{ppm}$ \\
Aktivitas Antioksidan & $30,38 \mathrm{ppm}$ & $89,73 \mathrm{ppm}$ \\
$(\mathrm{IC} 50)$ & & \\
\hline
\end{tabular}

\section{Aktivitas Antioksidan Tepung Okra}

Berdasarkan uji aktivitas antioksidan dengan metode DPPH diperoleh hasil $\mathrm{IC}_{50}$ tepung Okra adalah 30,38 ppm, sedangkan nilai IC $\mathrm{C}_{50}$ buah Okra adalah 89,73 ppm (Tabel 2). Oleh karena itu dapat disimpulkan bahwa tepung Okra masuk ke dalam kategori sangat kuat $(<50$ ppm) sebagai antioksidan dan buah Okra masuk ke dalam kategori kuat (50-100 ppm). Hasil penelitian ini sejalan dengan penelitian sebelumnya bahwa pengeringan buah Okra menjadi tepung dapat meningkatkan aktivitas antioksidan (Adelakun et al., 2009).

Nilai $I_{50}$ ini berbanding terbalik dengan aktivitas antioksidan, semakin tinggi aktivitas antioksidannya, maka nilai $I_{50}$ semakin rendah (Molyneux, 2004). Metode pengukuran kapasitas antioksidan menggunakan metode DPPH dikembangkan oleh Blois pada tahun 1958, dengan tujuan menentukan aktivitas antioksidan menggunakan radikal bebas stabil DPPH (adiphenyl- $\beta$-picrylhydrazyl) (Kedare and Singh, 2011). Sebanyak $70 \%$ aktivitas antioksidan dari Okra berasal dari komponen bioaktif yang bernama kuersetin dan turunannya, yang merupakan bagian dari polifenol, subkelas flavonol (Roy et al., 2014).

\section{Kesimpulan}

Berdasarkan hasil penelitian disimpulkan bahwa pengeringan buah Okra menjadi tepung Okra dapat meningkatkan aktivitas antioksidannya. Proses pengeringan tepung Okra dapat membuat tepung menjadi lebih cerah. Distribusi ukuran pertikel tepung Okra dinilai kecil sehingga mudah larut dalam air. Tepung Okra memiliki $\mathrm{pH}$ yang lebih asam dan konduktivitasnya yang lebih tinggi, padatan yang terlarut yang lebih tinggi jika dibandingkan dengan buahnya.

\section{Daftar Pustaka}

Al-Baarri, A.N., Legowo, A.M., Pramono, Y.B., Rizqiati, H., Pratama, Y., Masykuri, Widayat. 2019. Stability analysis of ginger (Zingiber officinale) emulsion affected by iota carrageenan. IOP Conference Series: Earth and Environmental Science 309:012038. DOI:10.1088/17551315/309/1/012038.

Alpizar-Reyes, E., Carrillo-Navas, H., Gallardo-Rivera, R., Varela-Guerrero, V., Alvarez-Ramirez, J., Pérez-Alonso, C. 2017. Functional properties and physicochemical characteristics of tamarind (Tamarindus indica L.) seed mucilage powder as a novel hydrocolloid. Journal of Food Engineering (209):68-75. 
DOI:10.1016/j.jfoodeng.2017.04.021

Adelakun O.E., Oyelade, O.J., Ade-omowaye, B.I.O., Adeyemi, I.A., Van De, V.M. 2009. Chemical composition and the antioxidative properties of Nigerian Okra Seed (Abelmoschus esculentus Moench) Flour. Food and Chemical Toxicology 47(6): 1123-1126. DOI: 10.1016/j.fct.2009.01.036.

Arapitsas, P. 2008. Identification and quantification of polyphenolic compounds from Okra seeds and skins. Food Chemical 110(4): 1041-1045. DOI: 10.1016/j.foodchem.2008.03.014.

Bernhardt, S., Schlich, E. 2006. Impact of different cooking methods on food quality: Retention of lipophilic vitamins in fresh and frozen vegetables. Journal Food Engineering 77(2): 327-333. DOI: 10.1016/j.jfoodeng.2005. 06.040 .

Carpin, M., Bertelsen, H., Dalberg, A., Bech, J.K., Risbo, J., Schuck, P., Jeantet, R. 2017. How does particle size in fluence caking in lactose powder. Journal of Food Engineering 209: 6167. DOI: 10.1016/j.jfoodeng.2017.04.006.

Chumyam, A., Whangchai, K., Jungklang, J., Faiyue, B. 2013. Effects of heat treatments on antioxidant capacity and total phenolic content of four cultivars of purple skin eggplants. Science Asia 39: 246-251. DOI: 10.2306/scienceasia15131874.2013.39.246.

Coskun, O., Kanter, M., Korkmaz, A., Oter, S. 2005. Quercetin, a flavonoid antioxidant, prevents and protects streptozotocin-induced oxidative stress and $\beta$-cell damage in rat pancreas. Pharmacological Research 51:117-123. DOI: 10.1016/j.phrs.2004.06.002.

Dadali, G., Apar D.K., Ozbek, B. 2017. Color change kinetics of Okra undergoing microwave drying color change kinetics of Okra undergoing microwave drying. Drying Technology 3937:925-936. DOI: 10.1080/07373930 701372296.

Edwards, R.L., Lyon, T., Litwin, S.E., Rabovsky, A., Symons, J.D. 2018. Quercetin reduces blood pressure in hypertensive subjects. The Journal of Nutrition 137(11):2405-2411. DOI:10.1093/jn/137.11.2405.

El, S.N., Karakaya, S. 2004. Radical scavenging and iron-chelating activities of some greens used as traditional dishes in Mediterranean diet. International Journal Food Science Nutrition 55:67-74. DOI:10.1080/0963748031000164 2501.

Fan S., Zhang, Y., Sun, Q., Yu, L., Li, M., Zheng, B., Wu, X., Yang, B., Li, Y., Huang, C. 2014. Extract of Okra lowers blood glucose and serum lipids in high-fat dietinduced obese C57BL/6 mice. Journal Nutrition Biochemical 25(7):702-709. DOI:10.1016/j.jnutbio.2014. 02.010.

Filler, K., Lyon, D., Bennett, J., McCain, N., Elswick, R., Lukkahatai, N., Saligan, L.N. 2014. Association of mitochondrial dysfunction and fatigue: a review of the literature. BBA Clinical (1):12-23. DOI:10.1016/j.bbacli.2014.04.001.

Giacco, F., Brownlee, M. 2014. Oxidative stress and diabetic complications. The American Heart Association: 1058-1070. DOI:10.1161/CIRC RESAHA.110.223545.

Imanningsih, N. 2012. Profil gelatinisasi beberapa formulasi tepung-tepungan untuk pendugaan sifat pemasakan. Penelitian Gizi dan Makanan 35(1):13-22.

Juin, F., Shan, Y., June, M., Dee, W. 2012. Effects of Chinese domestic cooking methods on the carotenoid composition of vegetables in Taiwan. LWT - Food Science and Technology 46(2):485-492. DOI:10.1016/j.Iwt.2011.11. 019.

Kedare, S.B., Singh, R.P. 2011. Genesis and development of DPPH method of antioxidant assay. Journal of Food Science and Technology 48(4):412-422. DOI: 10.1007/ s13197-011-0251-1.

Krokida, M.K., Marinos, K. 2003. Drying kinetics of some vegetables. Journal of Food Engineering 59:391-403. DOI:10.1016/ S02608774(02)00498-3.

Lin, Y., Liu, H., Fang, J., Yu, C., Xiong, Y., Yuan, K. 2014. Anti-fatigue and vasoprotective effects of quercetin-3-O-gentiobiose on oxidative stress and vascular endothelial dysfunction induced by endurance swimming in rats. Food and Chemical Toxicology 68: 290-296. DOI:10.1016/j.fct.2014.03.026.

Lombard, K., Peffley, E., Geoffriau, E., Thompson, L., Herring, A. 2005. Quercetin in onion (Allium cepa $\mathrm{L}$.) after heat-treatment simulating home preparation. Journal of Food Composition and Analysis 18:571-581. DOI:10.1016/j.jfca. 2004.03.027.

Mendoza, F., Petr, D.J.M., Aguilera. 2007. Colour and texture analysis in classification of commercial potato chips. Food Research International 40:1146-1154. DOI:10.1016/j.foodres.2007. 06.014.

Miglio, C., Chiavaro, E., Visconti, A., Fogliano, V., Pellegrini, N. 2008. Effects of different cooking methods on nutritional and physicochemical characteristics of selected vegetables. Journal Agriculture Food Chemical 56:139-147. DOI:10.1021/jf072304b.

Molyneux, P. 2004. The use of the stable free radical diphenylpicryl-hydrazyl (DPPH) for estimating antioxidant activity. Songklanakarin Journal of Science and Technology 26:211-219. DOI:10.1287/isre.6.2.144.

Pangesti, Y.D, Parnanto, N.H.R., Achmad, R.A. 2014. Kajian sifat fisikokimia tepung bengkuang (pachyrhizus erosus) dimodifikasi secara heat moisture treatment (HMT) dengan variasi suhu. Jurnal Teknosains Pangan 3(3):72-77.

Pellegrini, N., Miglio, C., Rio, D., Salvatore, S., Serafini, M., Brighenti, F. 2009. Effect of domestic 
cooking methods on the total antioxidant capacity of vegetables. International Journal of Food Sciences and Nutrition 60 Suppl 2:12-22. DOI: $10.1080 / 09637480802175212$.

Roy, A., Shrivastava, S.L., Mandal, S.M. 2014. Functional properties of Okra Abelmoschus esculentus L. (Moench): traditional claims and scientific evidences. Plant Science Today 1:121-130. DOI:10.14719/pst.2014.1.3.63.

Sa'eed, H.B., Neela, B. 2016. Nutrient profile, bioactive components, and functional properties of Okra (Abelmoschus esculentus (L.) Moench). Bioactive Foods in Health Promotion. Academic Press, US. Page 365-409. DOI: 10.1016/B978-0-12-802972-5.00018-4.

Sabitha V., Ramachandran S., Naveen K.R., Panneerselvam K. 2012. Investigation of in vivo antioxidant property of Abelmoschus esculentus (L) Moench fruit seed and peel powders in streptozotocin induced diabetic rats. Journal of Ayurveda \& Integrative Medicine 3(4):188-193. DOI: 10.4103/09759476.104432.

Sacks, E.J., Francis, D.M. 2001. Genetic and Environmental Variation for Tomato Flesh Color in a Population of Modern Breeding Lines. Journal of the American Society for Horticultural Science 126(2):221-226. DOI:10.21273/JASHS.126.2.221.

Sheu, S.C., Lai, M.H. 2012. Composition analysis and immuno-modulatory effect of Okra (Abelmoschus esculentus L.) extract. Food Chemical 134(4):1906-1911. DOI:10.1016/j. foodchem.2012.03.110.

Suica-Bunghez, I.R., Teodorescu, S., Dulama, I.D., Voinea, O.C., Simionescu, S., Ion, R.M. 2016. Antioxidant activity and phytochemical compounds of snake fruit (Salacca zalacca). International Conference on Innovative Research 133:1-8. DOI:10.1088/1757899X/133/1/012051.

Turkmen, N., Sari, F., Velioglu, Y.S. 2005. The effect of cooking methods on total phenolics and antioxidant activity of selected green vegetables. Food Chemistry 93: 713-718. DOI: 10.1016/j.foodchem.2004.12.038.

Ubwa, S.T., Tyohemba, R.L. Oshido, B.A., Amua, Q.M. 2014. Chemical analysis of some wild underutilized mucilaginous vegetables and a domesticated vegetable in benue state, Nigeria. British Journal of Applied Science \& Technology 4(32):4566-4574. DOI:10.9734/BJAST/2014/12241.

Zhang, Z.L. 2014. Antioxidative and glucose homeostatic effects of extracts and isolated components from Okra (Abelmoschus esculentus Fruits). Molecules 24(1)38-50. DOI:10.1016/j.jnutbio.2014.02.010.

Zhu, Q.Y., Huang, Y., Chen, Z.Y. 2000. Interaction between flavonoids and a-tocopherol in human low density lipoprotein. Journal Nutrition Biochemical 11(1):14-21. DOI:10. 1016/S0955-2863(99)00065-0. 